\title{
Policy Implications of Allocation Methods in the Life Cycle Analysis of Integrated Corn and Corn Stover Ethanol Production
}

\author{
Christina E. Canter $^{1}$ (D) - Jennifer B. Dunn ${ }^{1}$ - Jeongwoo Han ${ }^{1}$. \\ Zhichao Wang ${ }^{2} \cdot$ Michael Wang ${ }^{1}$
}

Published online: 18 August 2015

(C) The Author(s) 2015. This article is published with open access at Springerlink.com

\begin{abstract}
A biorefinery may produce multiple fuels from more than one feedstock. The ability of these fuels to qualify as one of the four types of biofuels under the US Renewable Fuel Standard and to achieve a low carbon intensity score under California's Low Carbon Fuel Standard can be strongly influenced by the approach taken to their life cycle analysis (LCA). For example, in facilities that may co-produce corn grain and corn stover ethanol, the ethanol production processes can share the combined heat and power (CHP) that is produced from the lignin and liquid residues from stover ethanol production. We examine different LCA approaches to corn grain and stover ethanol production considering different approaches to CHP treatment. In the baseline scenario, CHP meets the energy demands of stover ethanol production first, with additional heat and electricity generated sent to grain ethanol production. The resulting greenhouse gas (GHG) emissions for grain and stover ethanol are 57 and $25 \mathrm{~g}$ $\mathrm{CO}_{2} \mathrm{eq} / \mathrm{MJ}$, respectively, corresponding to a 40 and $74 \%$
\end{abstract}

Christina E. Canter

ccanter@anl.gov

Jennifer B. Dunn

jdunn@anl.gov

Jeongwoo Han

jhan@anl.gov

Zhichao Wang

zwang@ecoengineers.us

Michael Wang

mqwang@anl.gov

1 Systems Assessment Group, Energy Systems Division, Argonne National Laboratory, 9700 South Cass Avenue, Argonne, IL 60439, USA

2 Present address: EcoEngineers, 300 East Locust Street, Suite 313, Des Moines, IA 50309, USA reduction compared to the GHG emissions of gasoline. We illustrate that emissions depend on allocation of burdens of CHP production and corn farming, along with the facility capacities. Co-product handling techniques can strongly influence LCA results and should therefore be transparently documented.

Keywords Ethanol · Corn · Corn stover · GHG emissions · Integrated facility $\cdot$ Life cycle analysis

\section{Introduction}

In 2014, the USA produced 54 billion liters of ethanol [1]. The country exported 3.0 billion liters and imported 2.7 billion liters. Two hundred ten ethanol biorefineries in 28 states contributed to ethanol production [2]. Iowa has the largest ethanol production capacity at over 15 billion liters per year (BLY), followed by Nebraska at almost 7.6 BLY [3]. Production occurs as far west as California and as far south as Louisiana. The predominant feedstock is corn grain, but some ethanol plants use a corn/sorghum blend, sugar cane bagasse, cheese whey, and various waste biomass as feedstocks. Plants have been built in the past few years to convert corn stover to ethanol. Since 2012, 1.4 million gallons of cellulosic ethanol has come onto the US market [4]. This volume is expected to increase as two cellulosic ethanol projects move towards capacity-level production. Construction is nearly complete at a DuPont facility in Iowa projected to use 340,000 tonnes of corn stover a year to produce 100 million liters per year (MLY) of ethanol [5]. An operational Abengoa plant that converts cellulosic biomass to ethanol in Hugoton, Kansas, has a capacity of 95 MLY [6]. Approximately $80 \%$ of the biomass will be corn stover [7]. The remaining $20 \%$ will come from wheat straw, milo stubble, and switchgrass [6]. Another 
facility in Iowa, built by POET, was completed in the late 2014 and uses approximately 250,000 tonnes of corn stover per year to produce 75 MLY of ethanol [3, 8].

One interesting aspect that POET has pursued is to colocate production of cellulosic ethanol next to a corn grain ethanol plant. One objective of this strategy is to increase total ethanol output from the biorefinery to 3.8 BLY [8]. Another advantage of the co-location of ethanol production from the two feedstocks is that the heat and power available from combustion of the lignin fraction of the stover and other liquid residues could be shared between the two ethanol production trains [9]. While this co-location and subsequent heat integration could save energy and reduce costs (besides cost savings from sharing ethanol storage and transportation logistics), it raises interesting life cycle analysis (LCA) questions as to how to allocate conversion process greenhouse gas (GHG) intensities to the corn grain ethanol and corn stover ethanol. Furthermore, the feedstock production stage of ethanol's life cycle can be revisited with an eye towards viewing corn grain and stover harvest as an integrated system rather than as two independent systems. Decisions about how to treat feedstock production stage and conversion stage GHG emissions will influence corn grain and corn stover ethanol's life cycle GHG emissions.

The Renewable Fuel Standard (the so-called RFS2), included in the Energy Policy Act of 2007, defined four types of biofuels and outlined the volume of renewable fuels that would be used in the country $[10,11]$. This legislation set volumetric targets for four biofuel categories with associated life cycle greenhouse gas (GHG) reduction thresholds when compared with a 2005 petroleum fuel baseline. RFS2 mandates that by 2022, 136 BLY of biofuels should be produced, with a maximum of 57 BLY coming from corn grain ethanol [12]. Corn ethanol must have life cycle greenhouse gas (GHG) emissions at least $20 \%$ below that of conventional gasoline. The RFS2 also mandates production of another biofuel category, called advanced biofuels, which must achieve a $50 \%$ reduction in GHG emissions compared to baseline fossil fuels. By 2022, 80 BLY of advanced biofuels should be produced. Cellulosic biofuels, another biofuel category, must have a $60 \%$ reduction in GHG emissions. Their target production by 2022 is 61 BLY. Cellulosic biofuels are made from cellulose, hemicellulose, or lignin. Ethanol produced from the fermentation of corn stover falls in this category [13]. Another biofuel category is biomass-based diesel. By 2022, 4 BLY of fuel that is $50 \%$ less GHG intensive that conventional diesel is the volumetric target and it has already been met [12].

The US Environmental Protection Agency (EPA) determines whether a given biofuel falls into any of the four categories established in the RFS2. To determine life cycle GHG emissions of biofuel pathways, which include GHG emissions from feedstock production and transportation, land-use change (LUC), feedstock conversion to fuel, fuel transportation, and fuel combustion, the EPA conducts life cycle analyses (LCA) that are specific to a certain feedstock (e.g., corn stover) and final fuel (e.g., ethanol) [14]. The EPA requires that each pathway subject to analysis has a single feedstock and single final fuel.

The estimation of life cycle GHG emissions of biofuel pathways also affects their attractiveness under California's Low Carbon Fuel Standard (LCFS), a performance-based standard that aims for a $10 \%$ reduction in GHG emission intensity of transportation fuels by 2020 relative to the 2010 level [15]. Similar to the EPA's approach, biofuel LCAs conducted to establish eligibility for the LCFS must consider a single feedstock's conversion to a single final fuel [16]. Oregon has recently adopted an LCFS that targets a $10 \%$ reduction in transportation fuel GHG intensity by 2025 [17]. Washington is also looking to adopt similar legislation [18]. Another piece of legislation in development for 11 other states is the Northeast and Mid-Atlantic LCFS.

In the case of the RFS2, each feedstock (or feedstock blend) must be converted to a single fuel product that would qualify as either a conventional, renewable, advanced, or cellulosic biofuel. (Corn ethanol is considered a "conventional" biofuel, essentially a subcategory within the renewable category because production of corn ethanol is capped at 15 billion gallons per year whereas production of other biofuels that could be classified as renewable is not capped.) This requirement forces allocation of GHG emissions from a single conversion facility processing more than one feedstock among the final fuel products and has significant implications for integrated production scenarios such as those pursued by POET. These biorefineries could produce a single biofuel stream containing some fuel molecules that could qualify as cellulosic biofuels and some that could qualify only as renewable (in the case of corn ethanol, conventional) biofuels. In the case of the LCFS, these different fuel molecules would contribute differing levels of emission reductions. It is an open question as to how to treat this blended fuel stream in biofuel LCA for regulation purposes, especially with the RFS2 biofuel categories.

Some previous studies have considered one or both of the life cycle GHG emissions and techno-economic aspects of combined processing of corn stover and corn grain. Murphy and Kendal [19], for example, examined the influence of different co-product handling techniques on the GHG intensity of co-produced corn and corn stover but did not examine the full life cycle of biofuels produced from these feedstocks combined. Several studies [20-22] examined how corn stover might be integrated as a source of biopower at corn ethanol plants, but two of these studies were limited to a technoeconomic perspective and did not consider life cycle GHG emissions. In addition, Ou et al. [23] examined the economic performance of co-located corn grain and stover ethanol plants. Finally, Kauffman et al. [24] consider converting corn grain and corn stover produced on the same hectare of land to 
ethanol and gasoline (via pyrolysis), respectively, and calculate the life cycle GHG emissions of these fuels. The analysis does not consider co-location of the pyrolysis and ethanol plants and how they might share utilities. None of these studies consider the sensitivity of life cycle GHG emissions of coproduced fuels to co-product handling techniques and the ensuing renewable fuel policy (RFS, LCFS) implications.

In this paper, we examine the implications of different approaches to estimating life cycle GHG emissions of corn grain ethanol and corn stover ethanol produced at an integrated biorefinery. We develop results for a single ethanol stream and for separate ethanol streams produced either from corn grain or corn stover. In the latter case, we examine the influence of treatment of feedstock production as separate or integrated and of the treatment of combined heat and power (CHP)-produced energy at the conversion facility. The objective of this analysis is to illuminate challenges in applying the RFS2 and LCFS frameworks to biorefineries integrating corn grain and corn stover ethanol production. Conclusions of this work could also apply to integrated biorefineries that use multiple feedstocks to produce other biofuels besides ethanol.

\section{Methods}

The life cycle GHG emissions of biofuels can be estimated through LCA using a model such as Argonne National Laboratory's Greenhouse gases, Regulated Emissions and Energy use in Transportation (GREET ${ }^{\mathrm{TM}}$ ). The US EPA used GREET, along with several other models, in developing life cycle GHG estimates for biofuels addressed in the RFS2 [14]. CARB uses a California-specific version of GREET (CAGREET) to develop estimates of the life cycle GHG intensity of biofuel pathways for its LCFS legislation [25]. In this analysis, we use the GREET version released in October 2014.

\section{Goal and Scope}

This study evaluates integrated ethanol production from both corn grain and corn stover. To conduct this analysis, the GREET model has been updated to model this integrated system in addition to the existing, separate corn grain and corn stover-to-ethanol pathways $[9,26]$. The unit processes and energy flows for the integrated scenario are presented in Fig. 1 and are based on Wang et al. (2012) and Humbird et al. (2011). Corn grain is farmed, harvested, and transported first to a collection location (i.e., grain elevator), then to the biorefinery, while corn stover is collected and transported to the same facility. Ethanol is produced from fermentation of the corn grain, along with a distiller grains solubles (DGS) coproduct, an animal feed. The corn stover, after pretreatment, is also fermented to produce ethanol, along with a liquid residue and lignin. The liquid residue is sent to anaerobic digestion to produce biogas, which is then sent to CHP along with the lignin. The CHP section of the facility produces both steam and electricity, which are then used in both corn and stover ethanol productions. Any excess electricity is exported to the grid.

The functional unit for this analysis is $1 \mathrm{MJ}$ of ethanol. Life cycle GHG emissions were calculated for corn grain and stover ethanol separately and for a single ethanol stream produced from both feedstocks. Figure 1 shows the boundary diagram for the integrated scenario. We treat $\mathrm{CO}_{2}$ emissions from ethanol combustion during vehicle operation as offset by carbon uptake during feedstock growth, which in the case of corn grain and corn stover occurred in the recent past. The net GHG emissions from ethanol combustion and carbon uptake are minimal and are estimated to be about $0.4 \mathrm{~g}-\mathrm{CO}_{2} \mathrm{eq} / \mathrm{MJ}$ depending on the $\mathrm{CH}_{4}$ and $\mathrm{N}_{2} \mathrm{O}$ emission factors of ethanol combustion. We include land-use change (LUC) GHG emissions. We describe our development of LUC GHG emissions that are used in this analysis in a separate publication [27].

\section{Baseline Scenario}

For corn farming, energy and material inputs were taken from a survey of 19 states which produced $95 \%$ of the total corn grain in the USA [28]. Material use includes fertilizers like nitrogen, phosphorus as $\mathrm{P}_{2} \mathrm{O}_{5}$, and potassium as $\mathrm{K}_{2} \mathrm{O}$. Herbicides and insecticides are also applied to corn fields. Corn farming consumes energy in the forms of diesel, gasoline, natural gas, liquefied petroleum gas, and electricity [29]. These fuels are used for both onsite activities and upstream in the production of fertilizers, herbicides, and insecticides. After harvest, the corn is transported by truck to grain elevators and later to the refinery. Additional parameters we use to model corn farming and transport are summarized in Table 1.

In the baseline scenario, corn stover is burdened only with the additional materials and energy consumed as a result of its collection as a biofuel feedstock. In this treatment, corn grain and corn stover are harvested with a multi-pass system which first harvests the corn grain and then the corn stover. The energy consumed during the second pass is assigned to only the corn stover. The consumption of supplemental fertilizers that replace the nutrients in the removed stover is attributed to the stover. If this stover remained on the field, these nutrients would have entered the soil. Material and energy inputs associated with corn stover are summarized in Table 2.

In this analysis, we consider co-located facilities to convert the grain and stover to ethanol. We assume a typical facility would produce 210 and $76 \mathrm{MGY}$ of grain and stover ethanol, respectively [9]. These volumes are based on the POET facility. Other biorefineries that co-produce ethanol from corn grain and corn stover will likely have different capacities that do the POET facility. In the USA, wet and dry mills convert corn to ethanol by fermentation. For this analysis, we consider 
Fig. 1 System boundary for ethanol production from an integrated corn and corn stover biorefinery process. Processes are presented in blue and material and energy flows in yellow. The red and green arrows represent heat and electricity flows, respectively

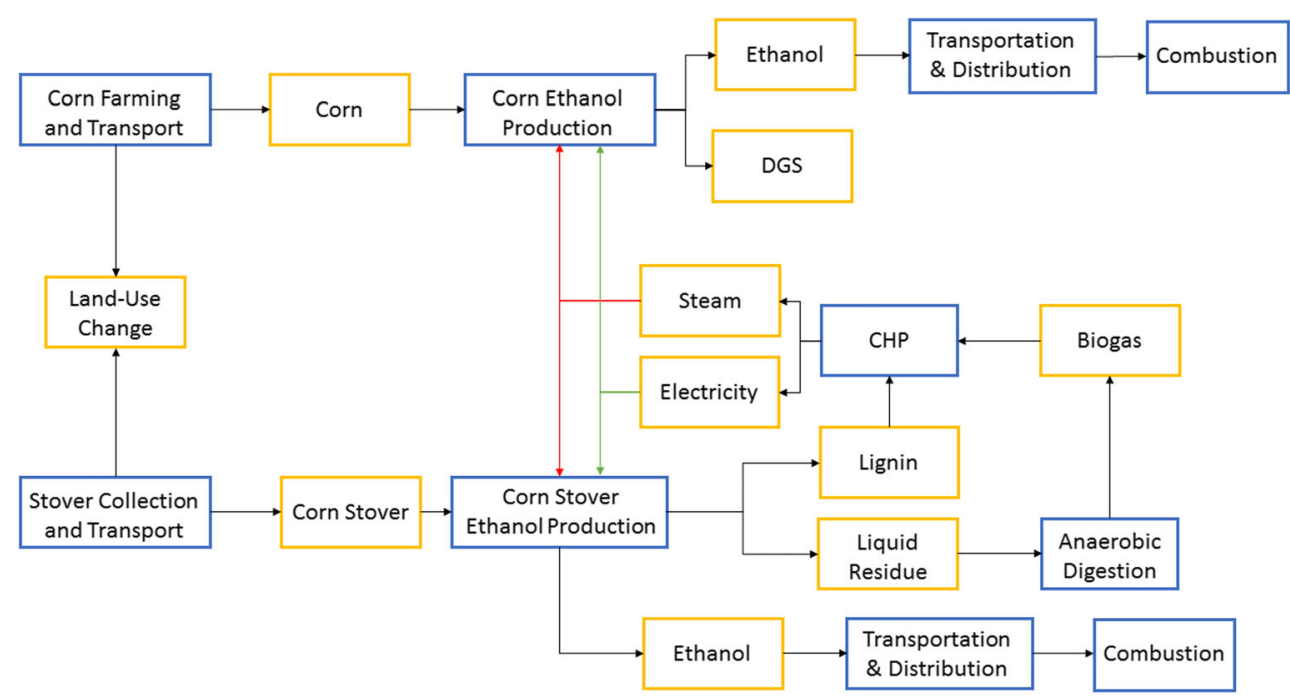

estimated based upon Humbird et al. (2011) and are summarized in Table 3. It is important to note that real-world corn stover ethanol plants may have different configurations and will certainly have different material and energy flows than the process as designed by Humbird et al. This peer-reviewed design case, however, enables analysis of this emerging biorefinery design.

When corn stover ethanol is considered to be produced at an isolated facility, surplus electricity could be available from the CHP plant and exported to the grid [9, 31]. In that case, the corn stover ethanol receives a fairly large GHG emission reduction credit (as much as $18 \mathrm{~g}-\mathrm{CO}_{2} \mathrm{eq} / \mathrm{MJ}$ ) for displacing conventional electricity. At an integrated facility, both corn grain and corn stover ethanol production could rely on the heat and electricity CHP produces, which reduces electricity and NG consumption in corn ethanol production. The impact of the internal displacement could be addressed properly by a process-level allocation. With a process-level allocation, the heat and electricity from CHP is considered a co-product of stover ethanol since they are derived from stover ethanol residues. Thus, the energy use and GHG emissions from corn stover harvesting, conversion, and LUC are allocated between

Table 2 Materials and energy consumed during corn stover collection, corn stover transportation, and the production of ethanol from corn stover (Argonne National Laboratory, 2014)

\begin{tabular}{lll}
\hline Parameter & Unit & Value \\
\hline Stover removal rate & dry tonne/ha & 2.2 \\
Stover harvest energy & MJ diesel/ha & 470 \\
Stover transportation energy & $\mathrm{MJ} /$ dry tonne & 70 \\
Additional nitrogen & $\mathrm{kg} /$ dry tonne stover & 8.8 \\
Additional $\mathrm{P}_{2} \mathrm{O}_{5}$ & $\mathrm{~kg} /$ dry tonne stover & 2.5 \\
Additional $\mathrm{K}_{2} \mathrm{O}$ & $\mathrm{kg} /$ dry tonne stover & 15 \\
Stover ethanol yield & L ethanol/dry tonne & 32 \\
\hline
\end{tabular}


Table 3 Energy and materials consumed and energy produced during ethanol production at an integrated corn grain and corn stover plant. Amounts are presented for $1 \mathrm{~L}$ of grain, stover and total ethanol production (from both feedstocks)

\begin{tabular}{llll}
\hline Parameters & Grain ethanol & Stover ethanol & Integrated ethanol \\
\hline Stover ethanol yield (L/dry tonne) & & 32 & \\
Grain ethanol yield (L ethanol/tonne grain) & 430 & & \\
Natural gas (MJ/L) & 7.5 & 0 & 5.5 \\
CHP electricity generated (MJ/L) & 0 & 2.6 & 0.7 \\
CHP heat generated (MJ/L) & 0 & 0.47 & 0.13 \\
Alpha amylase (g/L) & 0.67 & & 0.49 \\
Gluco amylase (g/L) & 1.4 & & 1.1 \\
Cellulase (g/L) & & 30 & 8.0 \\
Yeast (g/L) & 0.73 & 7.5 & 2.5 \\
Sulfuric acid (g/L) & 4.8 & 91 & 28 \\
Ammonia (g/L) & 4.8 & 11 & 6.4 \\
Corn steep liquor $(\mathrm{g} / \mathrm{L})$ & & 35 & 9.3 \\
DAP $(\mathrm{g} / \mathrm{L})$ & & 3.7 & 0.98 \\
NaOH $(\mathrm{g} / \mathrm{L})$ & 6.0 & 31 & 13 \\
CaO $(\mathrm{g} / \mathrm{L})$ & 2.9 & 20 & 7.5 \\
Urea $(\mathrm{g} / \mathrm{L})$ & & 5.5 & 1.5 \\
\hline
\end{tabular}

stover ethanol and generated electricity and heat by their energy content.

In the baseline scenario, the energy demands for stover ethanol production are met first; and any additional energy from CHP is applied to grain ethanol production. The DGS co-product of corn ethanol displaces conventional animal feed (corn and soybean meal); corn ethanol is assigned as the corresponding displacement credit $15 \mathrm{~g}-\mathrm{CO}_{2} \mathrm{eq} / \mathrm{MJ}$-corn ethanol [26]. It would also be possible to treat the corn grain ethanol and its dry DGS (DDGS) co-product with energy or market value allocation techniques [32], but those methods were not evaluated in this analysis.

\section{Alternative Allocation Scenarios}

Within an LCA of integrated corn grain and corn stover ethanol production, options exist as to how to allocate energy and environmental burdens among products and co-products of both the farming stage and the conversion stage. Certainly, it is worthwhile to examine these options because co-product allocation choices can influence LCA results [32]. Decisions about co-product allocation must be clearly documented so that LCA results are transparent. In the base case farming scenario, we apply an attributional approach to allocation and the only energy consumption and emission burdens tied to corn stover are those associated with stover collection and supplemental fertilizer application. Alternatively, energy and emission burdens of corn agriculture (including LUC) could be allocated between the grain and stover on a mass or energy basis (or market revenue based). In the case of mass allocation, GHG emissions are allocated based on the total mass of feedstock harvested from each unit area. The approach to allocating burdens on an energy basis is similar but replaces the mass of feedstock with its energy content. We investigated each of these alternative allocation scenarios.

In the conversion stage of the baseline scenario, the CHP energy is used to meet the demands of stover ethanol production first and any additional energy is sent to grain ethanol production. Two additional allocation methods for the CHP energy are evaluated in this paper and are summarized in Table 4. For scenario 1, CHP energy is split between the two feedstocks based on their percent contribution to the total ethanol produced. In this analysis, for the grain and stover facilities production 210 and 76 MLY, respectively, $73 \%$ of the CHP energy is assigned to grain ethanol production and the remaining $27 \%$ goes to stover ethanol production. In scenario 2, CHP energy is first used to meet the corn grain energy demands, with any additional energy going to stover ethanol production. Scenario 2 is probably not an appropriate allocation method because the CHP energy is generated from stover and the ethanol produced from that feed should benefit from that generation. Even though this scenario will reduce grain ethanol's GHG emissions, it is still investigated to highlight the effect of this approach.

\section{Results and Discussion}

\section{Baseline GHG Emissions}

The GHG emissions for corn grain and corn stover ethanol, separate and combined, for the baseline scenario in which the energy demands of the stover ethanol process are met first and are summarized in Fig. 2. All of the CHP heat is consumed, 
Table 4 CHP allocation scenarios as compared to the baseline. The demands for external energy are given for $1 \mathrm{~L}$ of grain, stover, and combined ethanol (from both feedstocks) after CHP heat and electricity are applied. The electricity demand for both feedstocks is met by CHP, so no additional electricity is required

\begin{tabular}{llllll}
\hline Scenario & Corn farming allocation & CHP energy share & $\begin{array}{l}\text { Corn } \\
\text { Natural gas (MJ/L) }\end{array}$ & $\begin{array}{l}\text { Stover } \\
\text { Natural gas (MJ/L) }\end{array}$ & $\begin{array}{l}\text { Integrated } \\
\text { Natural gas (MJ/L) }\end{array}$ \\
\hline Baseline & Attributional & Fulfill corn stover demand & 7.5 & 0 & 5.5 \\
1 & Attributional & Ethanol production allocation & 2.8 & 13 & 5.5 \\
2 & Attributional & Fulfill corn grain demand & 1.1 & 18 & 5.5 \\
\hline
\end{tabular}

${ }^{a}$ Heat and electricity are allocated based on the total amount of ethanol produced. For the integrated scenario, 73 and $27 \%$ of the ethanol come from corn grain and corn stover, respectively

and 5.5 MJ natural gas/liter of combined ethanol is imported. Corn grain and stover ethanol productions use 31.4 and $58.1 \%$ of CHP-generated electricity, respectively. The total electricity demand of both feedstocks is met, and $10.5 \%$ of the CHP electricity is surplus. This generated electricity is considered a co-product with a GHG burden of $25 \mathrm{~g}-\mathrm{CO}_{2} \mathrm{eq} / \mathrm{MJ}-$ electricity. For the baseline scenario, the net life cycle GHG emissions of corn grain ethanol are $57 \mathrm{~g}-\mathrm{CO}_{2} \mathrm{eq} / \mathrm{MJ}$. The largest portion of these emissions comes from corn farming and transportation at $35 \mathrm{~g}-\mathrm{CO}_{2} \mathrm{eq} / \mathrm{MJ}$, followed by ethanol production at $26 \mathrm{~g}-\mathrm{CO}_{2} \mathrm{eq} / \mathrm{MJ}$. The displacement of animal feed with DGS provides a $15 \mathrm{~g}-\mathrm{CO}_{2} \mathrm{eq} / \mathrm{MJ}$ credit. The net GHG emissions for stover ethanol are $25 \mathrm{~g}-\mathrm{CO}_{2} \mathrm{eq} / \mathrm{MJ}$. The largest contribution of these is from ethanol production (e.g., consumption of process chemicals and enzymes, imported energy) at $13 \mathrm{~g}-\mathrm{CO}_{2} \mathrm{eq} / \mathrm{MJ}$, followed by stover collection and transport at $11 \mathrm{~g}-\mathrm{CO}_{2} \mathrm{eq} / \mathrm{MJ}$. Corn grain ethanol and corn stover ethanol
LUC GHG emissions are 7.6 and -0.6 g- $\mathrm{CO}_{2} \mathrm{eq} / \mathrm{MJ}$, respectively, based on previous analysis [27].

Also presented in Fig. 2 are the combined ethanol GHG emissions, which are the total emissions of a single ethanol stream coming out of the integrated plant. Results are presented as a combined liter of ethanol, of which 73 and $27 \%$ come from corn grain and corn stover, respectively. The total GHG emissions of ethanol produced at the integrated plant are $48 \mathrm{~g}$ $\mathrm{CO}_{2} \mathrm{eq} / \mathrm{MJ}$, with the largest portion of the emissions coming from corn farming and transportation at $26 \mathrm{~g}-\mathrm{CO}_{2} \mathrm{eq} / \mathrm{MJ}$, then ethanol production at $23 \mathrm{~g}-\mathrm{CO}_{2} \mathrm{eq} / \mathrm{MJ}$. When the integrated scenario results are compared to gasoline, the combined ethanol liter achieves a $49 \%$ reduction assuming the GHG intensity of gasoline is $94 \mathrm{~g}-\mathrm{CO}_{2} \mathrm{eq} / \mathrm{MJ}$ [33]. When corn grain and corn stover ethanol are treated in isolation, the associated GHG emission reductions are 40 and $74 \%$, respectively. The result of corn stover ethanol when based on integrated
Fig. 2 GHG emissions for the baseline scenario when grain ethanol and stover ethanol are considered as separate and combined volumes of fuel

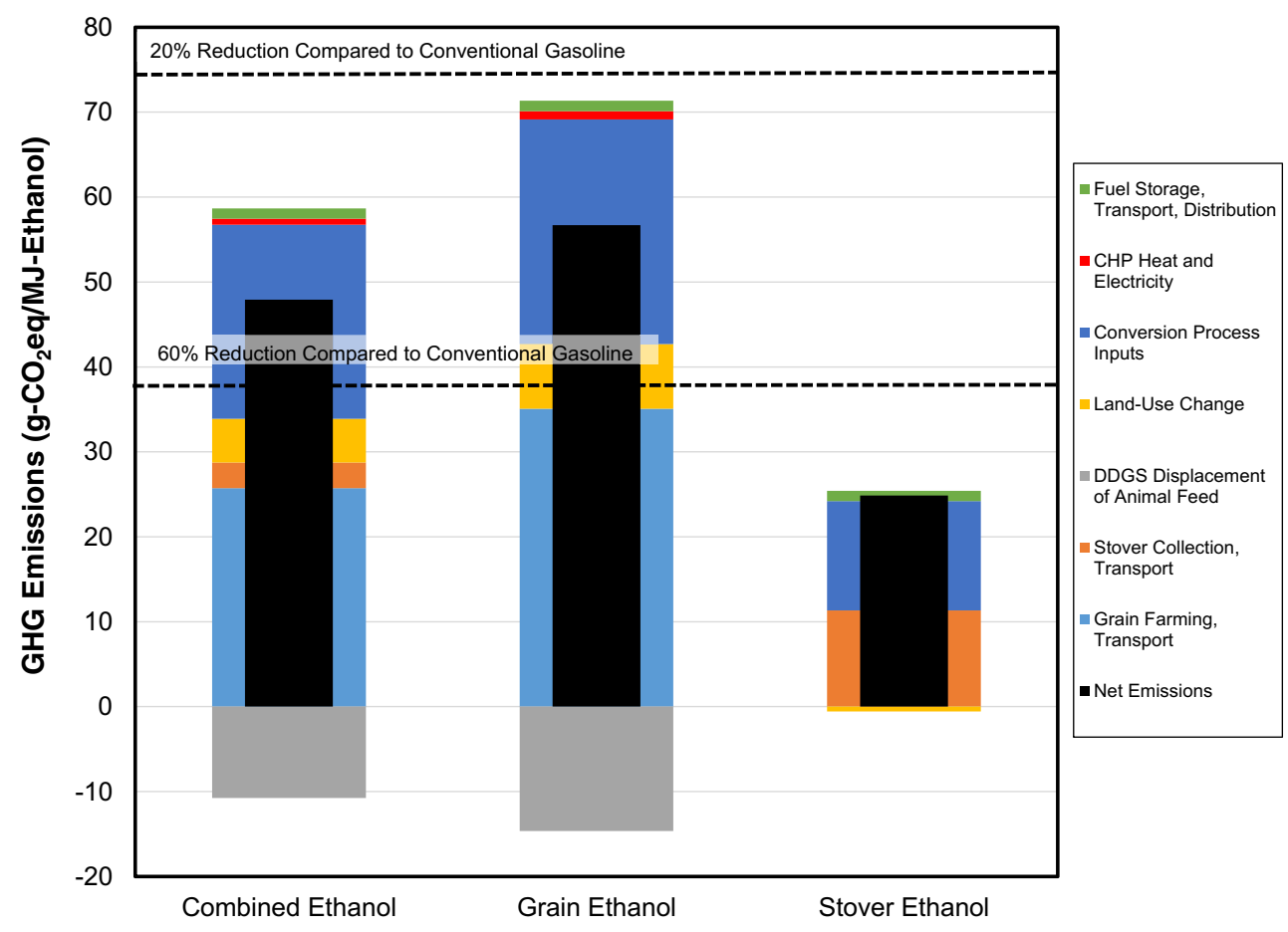


ethanol production is similar to previous studies with the GHG emissions of this fuel showing a marked emission reduction as compared to gasoline $(>60 \%)[13,26,34]$.

\section{Alternative Allocation Scenarios}

Figure 3 contains corn grain and stover ethanol life cycle GHG emission results for the baseline and two CHP allocation scenarios (Table 4). In scenario 1, ethanol production allocation, the stover ethanol GHG emissions increased from 24 to $43 \mathrm{~g}-\mathrm{CO}_{2} \mathrm{eq} / \mathrm{MJ}$ and the grain ethanol GHG emissions decreased from 57 to $50 \mathrm{~g}-\mathrm{CO}_{2} \mathrm{eq} / \mathrm{MJ}$ as compared to the baseline. Scenario 2 results mirror this trend with similar changes in results compared to the baseline. In this scenario, the life cycle GHG emissions of corn grain and corn stover ethanol are both $48 \mathrm{~g}-\mathrm{CO}_{2} \mathrm{eq} / \mathrm{MJ}$. The GHG emissions for the combined liter from the integrated facility for scenarios 1 and 2 remain the same as the baseline. This result is expected because these scenarios only affect how the CHP-produced heat and electricity are shared between the grain and stover ethanol and the amount of materials and energy entering the total system remains the same.

For the baseline, farming energy is allocated based on attribution, meaning the only operations assigned to the corn stover are the energy to collect and transport the stover to the biorefinery and burdens associated with supplemental fertilizer production, application, and fugitive $\mathrm{N}_{2} \mathrm{O}$ emissions. Allocating the total farming emissions based on the energy content of the feedstocks results in a decrease of the grain ethanol GHG emissions from 57 to $55 \mathrm{~g}-\mathrm{CO}_{2} \mathrm{eq} /$ $\mathrm{MJ}$ and an increase in the stover emissions from 25 to 40 $\mathrm{g}-\mathrm{CO}_{2} \mathrm{eq} / \mathrm{MJ}$. The change in the emissions for each feedstock stems from a change in the farming emissions. When energy allocation is applied to corn farming with stover harvest, the GHG intensity of corn grain ethanol decreases by $9 \%$, while it increases by $140 \%$ for corn stover ethanol. With the energy allocation scenario, both fuels provided a life cycle GHG emission reduction compared to gasoline of 42 and $57 \%$ for grain and stover ethanol, respectively. If mass rather than energy allocation is applied to feedstock production, similar values, 55 and $38 \mathrm{~g}-\mathrm{CO}_{2} \mathrm{eq} /$ $\mathrm{MJ}$, result for grain and stover ethanol, respectively. It is important to note, however, that this treatment of the collection of corn grain and corn stover as an integrated system may not accurately represent the feedstock production stage. At present, farmers may view stover harvest less as a means to produce an additional product from their land, but rather as a technique to manage rising crop residue levels as corn yields increase. This viewpoint is likely more prevalent in areas with high corn yields with a corresponding substantial stover resource.

\section{Treating CHP-Produced Heat and Electricity by Displacement}

In this paper, CHP-produced heat and electricity are considered as a co-product of corn stover ethanol production with associated energy and emission burdens. When corn stover ethanol is produced in an individual plant, a common approach to handle CHP-produced heat and electricity is a displacement method where all GHG emissions are allocated to the ethanol and additional electricity is exported to the grid with the ethanol receiving a displacement credit $[9,33]$. This methodology can also be applied to the integrated scenario.

When CHP-produced electricity and heat are treated with the displacement method, no GHG emissions are associated with the CHP-produced heat and electricity that is used internally in corn ethanol and corn stover ethanol production. As a result, when corn grain ethanol production consumes the CHP-produced energy, the ethanol receives the benefit of an emission-free energy source. All of the GHG emission burden associated with corn stover that serves as the CHP energy feedstock are assigned to corn stover ethanol production, regardless of the final fate of the CHP energy. In our analysis, we assume that the displaced electricity is produced from the national average grid mix, which is $0.5,26.1,41.5,19.5,0.3$, and $12.2 \%$ from residual oil, natural gas, coal, nuclear power, biomass, and others (e.g., hydro, geothermal), respectively [33]. The displacement credits are assigned to corn stover ethanol. We generated results for when this displacement method along with the attributional approach to corn grain and stover agriculture is applied to calculation of the GHG emissions for the baseline scenario. Corn stover receives the CHP-produced energy first. Compared to a scenario with the same assumptions except the energy allocation method applied to co-produced CHP, the GHG emissions for stover ethanol increase from 25 to $27 \mathrm{~g}-\mathrm{CO}_{2} \mathrm{eq} / \mathrm{MJ}$, while those for grain ethanol decrease from 57 to $54 \mathrm{~g}-\mathrm{CO}_{2} \mathrm{eq} / \mathrm{MJ}$. The change in emissions is relatively small because $88 \%$ of the heat and electricity is utilized by corn stover ethanol, meaning most of the emissions of the CHP co-product are assigned to the stover ethanol production in the baseline scenario. For this scenario, the GHG emission reduction is increased for corn grain from 40 to $42 \%$ but decreased for stover from 74 to $71 \%$. These results would leave the status of corn grain ethanol and corn stover ethanol as conventional and cellulosic biofuels, respectively. The GHG emissions for the combined liter decrease when CHP is considered a byproduct from 48 to $47 \mathrm{~g}-\mathrm{CO}_{2}$ eq/MJ. Unlike when CHP-generated electricity is considered a co-product, a displacement credit can be taken for the generated electricity that goes unused at the biorefinery.

The effects of treating CHP as a co-product rather than a byproduct have a greater effect when we consider scenario 1 , in which CHP energy is allocated based on ethanol 
Fig. 3 Breakdown of life cycle GHG emissions of corn grain and corn stover ethanol. The 20 and $60 \%$ GHG reduction targets are based on conventional gasoline GHG emissions of 94 g- $\mathrm{CO}_{2}$ eq/ MJ. Emissions from ethanol combustion and carbon uptake during feedstock growth, which essentially cancel (net GHG emissions of about $0.4 \mathrm{~g}-\mathrm{CO}_{2} \mathrm{eq} /$ $\mathrm{MJ})$, are excluded from this chart

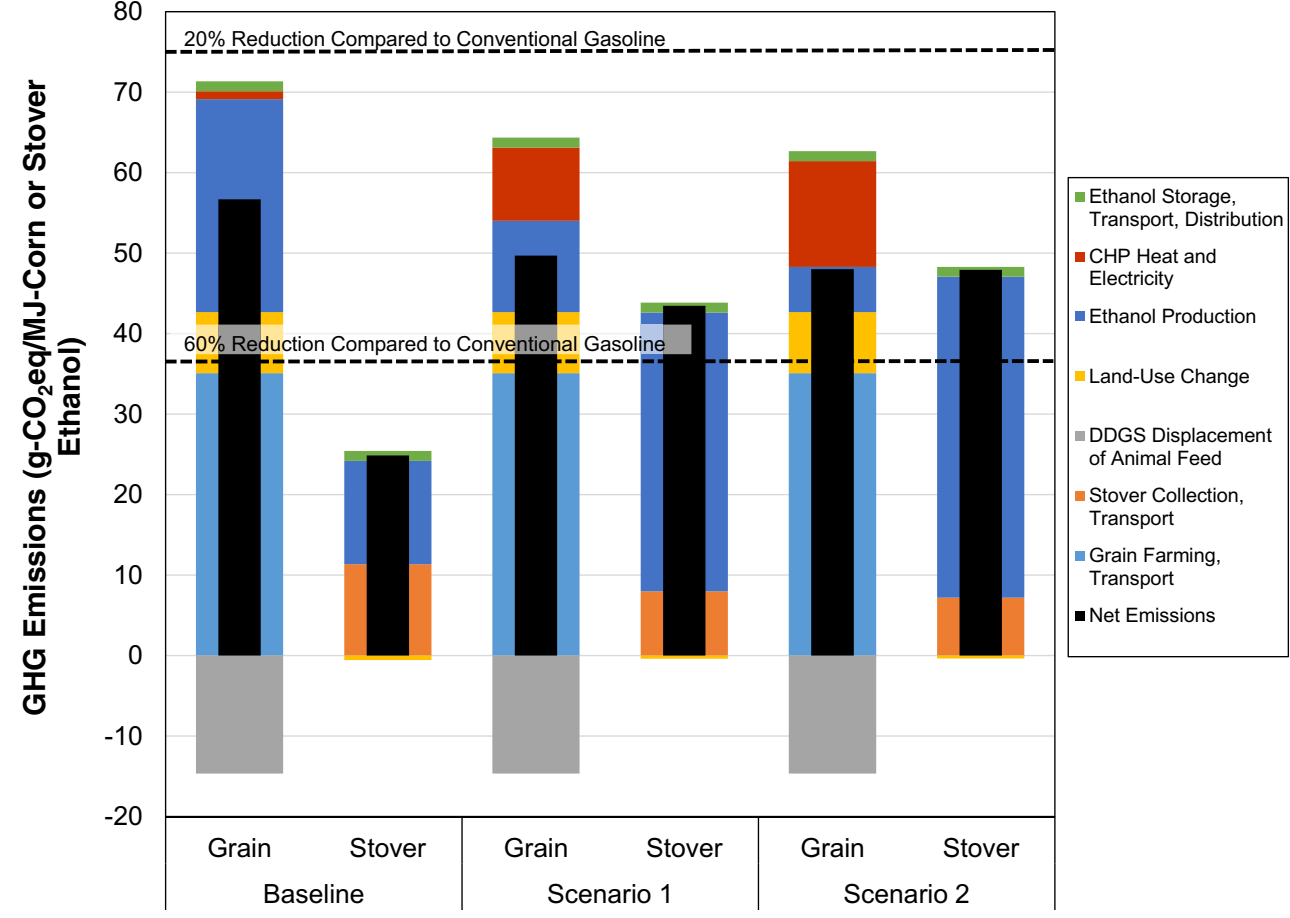

production. It is important to note that burdening corn stover ethanol production with the energy consumption and emissions associated with converting corn stover to CHPproduced energy that is subsequently used by the corn grain ethanol process is likely not an appropriate allocation method for an integrated plant. We present this scenario, however, to highlight the pronounced effect on results that these types of choices in LCA can have. In this case, which essentially ties the burden associated with CHP-produced energy to corn stover ethanol, the GHG emissions in this scenario decrease for grain ethanol from 48 to $40 \mathrm{~g}-\mathrm{CO}_{2} \mathrm{eq} / \mathrm{MJ}$, while they increase for stover ethanol from 48 to $69 \mathrm{~g}-\mathrm{CO}_{2} \mathrm{eq} / \mathrm{MJ}$. The effect of the assumption about CHP energy is much greater because, in this scenario, stover ethanol only utilizes $57 \%$ of the heat and electricity produced by CHP. Under these conditions, corn grain ethanol achieves a GHG emission reduction of $17 \%$. On the other hand, stover ethanol would only offer a $25 \%$ GHG reduction compared to gasoline and would only qualify as a renewable fuel under RFS2.

\section{Effect of Plant Size on GHG Emissions}

We selected corn grain and stover ethanol plant capacities based on information about commercial facilities [9]. As the industry expands and matures, plant capacities may change. We investigated the influence of plant capacity assumptions on integrated ethanol GHG emissions. In Fig. 4, we present GHG emissions of grain and stover ethanol as well as integrated ethanol when the stover ethanol plant size ranged from 0-210 MLY and the grain ethanol plant size was held constant at 210 MLY. The integrated and grain ethanol GHG emissions decrease with increasing plant size, but the emissions for stover ethanol are consistently $25 \mathrm{~g}-\mathrm{CO}_{2} \mathrm{eq} / \mathrm{MJ}$. The result makes sense because, in the baseline scenario, energy and material use for stover ethanol production are independent of corn grain ethanol production. On the other hand, grain ethanol GHG emissions show the increasing benefits of heat and electricity integration with an increasing stover ethanol plant size. Figure 4 shows two slopes for grain ethanol GHG emissions. Between stover ethanol plant sizes of 0 and $60 \mathrm{MLY}$, the GHG emissions for grain ethanol decrease from $62-57 \mathrm{~g}-\mathrm{CO}_{2} \mathrm{eq} / \mathrm{MJ}$. In this range, the corn grain ethanol plant benefits from CHP-produced electricity that increases as the stover ethanol plant capacity grows. Beyond a stover ethanol plant size of $60 \mathrm{MLY}$, corn grain ethanol GHG emissions see only a minor decrease from 57-56 g$\mathrm{CO}_{2}$ eq/MJ because, beyond this threshold, electricity consumption during grain ethanol production can be completely met by CHP-produced electricity. As corn stover ethanol plant capacity increases beyond 15 MLY, corn grain ethanol continues to benefit from increasing amounts of CHPproduced heat, which is reflected in the slow decline of corn grain ethanol GHG emissions beyond this point. The heat demand for grain ethanol $(7.8 \mathrm{MJ} / \mathrm{L})$ is more than ten times as large as the electricity demand $(0.7 \mathrm{MJ} / \mathrm{L})$. To produce enough energy to meet the heat and electricity demands for both grain and stover ethanol (with large amount of excess electricity), the corn stover ethanol production facility would need to be larger than $2700 \mathrm{MLY}$, an unrealistic size for a grain ethanol plant sized at 210 MLY. 
Fig. 4 Life cycle GHG emissions of ethanol produced from an integrated corn grain and corn stover ethanol plant for varying stover ethanol plant size. The grain ethanol plant size was held constant at $55 \mathrm{MGY}$

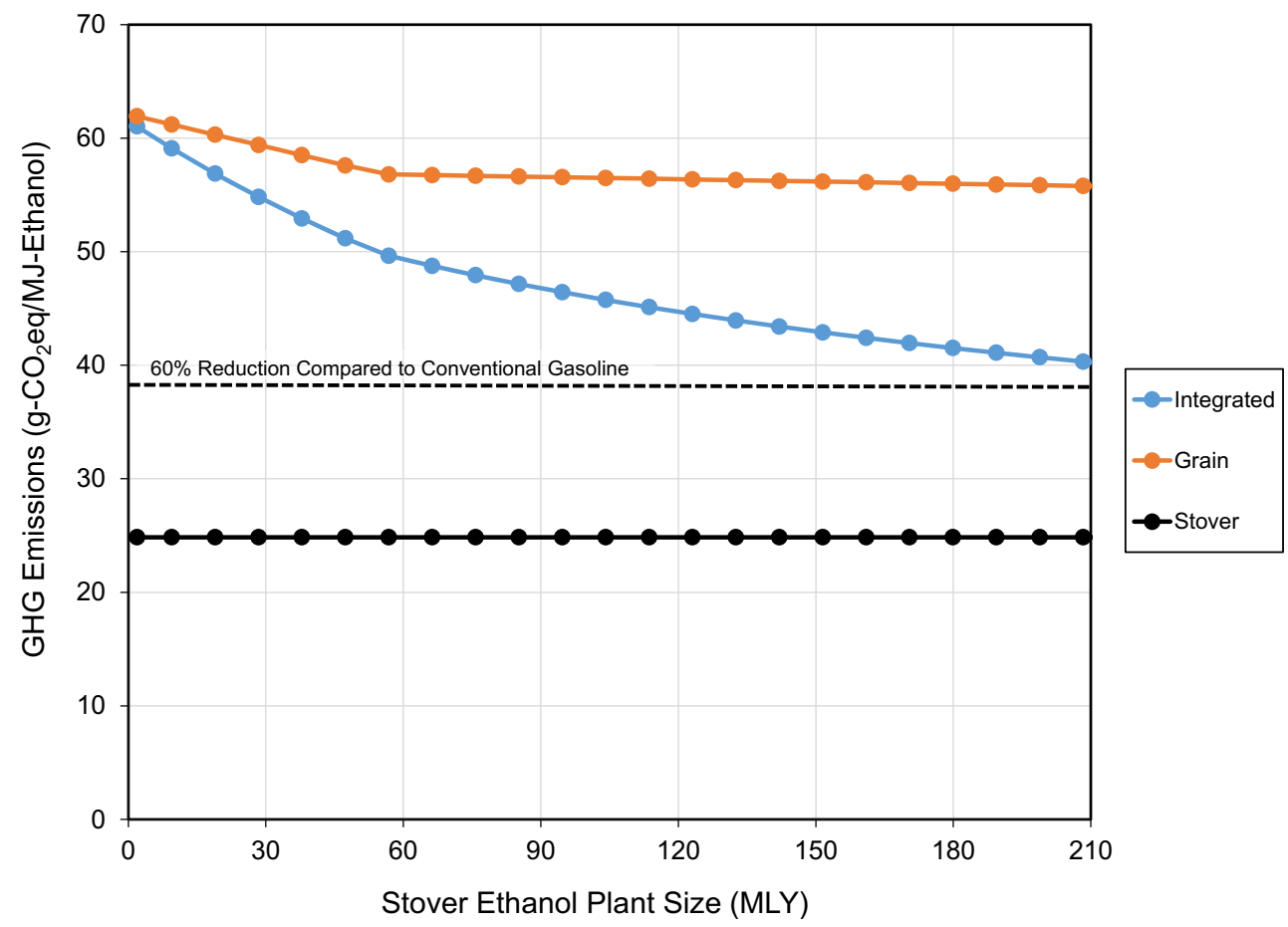

\section{Comparison of Life Cycle GHG Emissions}

from Integrated Versus Separate Analysis of Co-Produced Corn Grain and Corn Stover Ethanol

Figure 5 summarizes life cycle GHG emission results for corn grain and corn stover ethanol co-produced at one facility from integrated and separate analytical perspectives. The figure includes results for the baseline and the two alternative CHP scenarios (meeting the grain energy demands first and allocating CHP energy based on the share of the total ethanol produced). Included in this figure are lines that indicate the life cycle GHG emissions for corn grain ethanol and corn stover ethanol when they are produced at separate facilities [26]. The corn grain ethanol GHG emissions are for a dry mill facility
Fig. 5 Net GHG emissions for corn grain and stover ethanol for the baseline and the two alternative CHP usage scenarios. The 20,50 , and $60 \%$ GHG reduction lines represent the targets for the corresponding reduction in GHG emissions compared with gasoline at $94 \mathrm{~g}$ $\mathrm{CO}_{2} \mathrm{eq} / \mathrm{MJ}$. The lines for grain ethanol and stover ethanol represent the GHG emissions to produce ethanol in a nonintegrated scenario

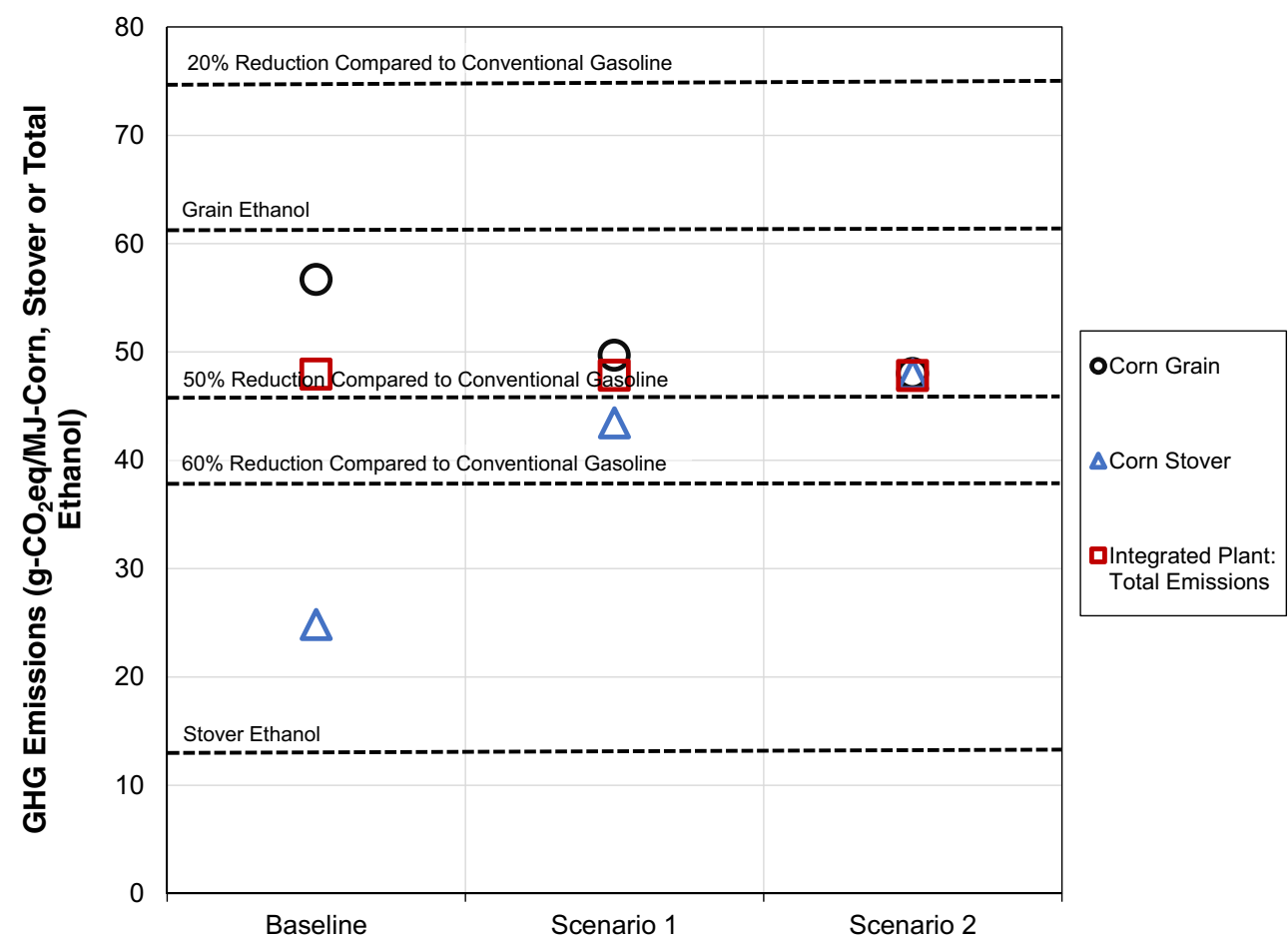


that produces only DDGS as a co-product, with natural gas as the process fuel. Additionally, the figure indicates the level of GHG emissions that would qualify biofuels as meeting the RFS standards for 20,50 , and $60 \%$ reduction as compared to gasoline.

It is clear that regardless of whether analysis of corn ethanol considers it apart from or together with corn stover ethanol as an integrated liter of ethanol or as a separate liter of ethanol, this biofuel can achieve a $20 \%$ reduction in GHG emissions as compared to baseline gasoline and qualify as a conventional biofuel under the RFS2. (Corn ethanol is not eligible for classification as an advanced or cellulosic biofuel, even if it achieves the GHG emission targets for these fuel categories.) Decisions about LCA methodology, however, strongly affect life cycle GHG results for corn stover ethanol, currently considered to be one of the most promising cellulosic biofuels in the USA. For the alternative CHP scenarios, created solely from changes in accounting technique rather than any physical, on-the-ground change in the life cycle of this biofuel, it no longer offers GHG emissions at a 50 or $60 \%$ GHG reduction compared to gasoline to be classified as an advanced or cellulosic biofuel, respectively.

\section{Conclusions and Policy Implications}

One objective of biofuel policies like the RFS2 and LCFS is to increase production volumes of biofuels with large reductions in life cycle GHG emissions as compared to baseline fossil fuels (gasoline, diesel). In this analysis, we examine different LCA scenarios that could influence the volume of high-GHG reduction fuels that integrated corn grain-corn stover ethanol facilities produce. The LCA methodology applied to these facilities can have a direct bearing on the success of biofuel policies. On the one hand, if corn grain ethanol and corn stover ethanol continue to be treated separately as required by RFS2 although they are produced at one facility, LCA methodology choices could increase or decrease volumes of conventional ( $20 \%$ GHG reduction), advanced (50\% GHG reduction), and cellulosic (60\% GHG reduction) ethanol the facility produces. While the treatment we adopted as the baseline scenario maintains corn stover ethanol as a biofuel that achieves a greater than $60 \%$ reduction as compared to gasoline, the treatments we adopted for scenarios 1 and 2 cause corn stover ethanol to qualify only as a renewable fuel or maybe an advanced biofuel under RFS2 if certain process improvements were realized. Just a $3 \%$ reduction in the ethanol facility energy requirement for scenario 1 and a $10 \%$ reduction for scenario 2 allow stover ethanol to qualify as an advanced biofuel. Under all scenarios, corn grain ethanol remains in the category of conventional biofuel, but the GHG emission reductions are very close to advanced biofuel emission levels (50\% GHG reduction). However, RFS2 prohibits grain ethanol from consideration as an advanced biofuel, even if it meets the GHG emission reduction target.

Even though corn grain ethanol is excluded from the advanced biofuel classification, the integrated scenario still produces ethanol with lower GHG emissions than from an individual plant. In theory, the integrated ethanol pathway is allowed in LCFS certification. Thus, this reduction can help states implementing an LCFS to meet their GHG emission reduction targets for transportation fuels. It is important to note that co-product handling techniques applied to corn grain and stover harvest and CHP-produced energy have a strong influence on results. These techniques raise allocation and crediting issues and can cause LCA to become convoluted and out of touch with the physical system under analysis. Co-product handling techniques that are adopted in biofuel LCA must be documented transparently for the results to be interpreted, especially if they will be applied in a policy context.

In conclusion, as biorefineries expand and mature, they may well use more than one feedstock and produce more than one product. LCAs of these products could adopt many different approaches that will influence the output of different categories of biofuels from these refineries. LCA methodology choices should reflect to the extent possible the physical system subject to analysis and should be transparent. Currently, biofuel policies force separate treatment of fuels that may be co-produced at integrated facilities, which moves the analysis away from this desired reflection of the physical reality of the biorefinery. This construct influences the ability of policies to meet their intended outcomes, and an open dialogue is necessary to examine the influence of LCA requirements of these policies and the application of these policies in the broader community.

Acknowledgments This work was supported by the Bioenergy Technologies Office (BETO) of the Office of Energy Efficiency and Renewable Energy of the United States Department of Energy, under Contract DE-AC02-06CH11357. The authors thank Alicia Lindauer, Kristen Johnson, and Zia Haq of the Bioenergy Technologies Office for their support and guidance.

Open AccessThis article is distributed under the terms of the Creative Commons Attribution 4.0 International License (http:// creativecommons.org/licenses/by/4.0/), which permits unrestricted use, distribution, and reproduction in any medium, provided you give appropriate credit to the original author(s) and the source, provide a link to the Creative Commons license, and indicate if changes were made.

\section{References}

1. Renewable Fuels Association (2015) Monthly U.S. Fuel ethanol production/demand. http://ethanolrfa.org/pages/monthly-fuelethanol-production-demand. Accessed 6 Apr 2015

2. Renewable Fuels Association (2014) Statistics. http://www. ethanolrfa.org/pages/statistics. Accessed 6 Apr 2015 
3. Renewable Fuels Association (2014) Falling walls \& rising tides. http://www.ethanolrfa.org/page/-/rfa-association-site/Resource\% 20Center $/ 2014 \% 20$ Ethano $\% 20$ Industry\%20Outlook.pdf?nocdn= 1. Accessed 9 Jan 2015

4. U.S. Environmental Protection Agency (2015) RFS2 EMTS Informational Data. In: Fuels Fuel Addit. http://www.epa.gov/ otaq/fuels/rfsdata/index.htm. Accessed 14 Jul 2015

5. Dupont (2015) DuPont Nevada site cellulosic ethanol facility. http://biofuels.dupont.com/cellulosic-ethanol/nevada-sitece-facility/. Accessed 19 Jan 2015

6. Fuels America (2014) Four commercial scale cellulosic ethanol biorefineries to enter production this year. http://www. fuelsamerica.org/blog/entry/four-commercial-scale-cellulosicethanol-biorefineries-to-enter-production. Accessed 19 Jan 2015

7. Biomass Magazine (2014) Abengoa celebrates grand opening of cellulosic ethanol plant. http://biomassmagazine.com/articles/ 11068/abengoa-celebrates-grand-opening-of-cellulosic-ethanolplant. Accessed 19 Jan 2015

8. POET DSM (2015) Cellulosic ethanol. http://poet.com/cellulosic. Accessed 19 Jan 2015

9. Wang Z, Dunn JB, Wang MQ (2014) Updates to the corn ethanol pathway and development of an integrated corn and corn stover ethanol pathway in the GREET model. Report No. ANL/ESD-13/9

10. U.S. Environmental Protection Agency (2014) Renewable Fuel Standard (RFS). In: Fuels Fuel Addit. http://www.epa.gov/oms/ fuels/renewablefuels/. Accessed 9 Jan 2015

11. 110th Congress of the United States (2007) Energy independence and security act of 2007. http://www.gpo.gov/fdsys/pkg/BILLS110hr6enr/pdf/BILLS-110hr6enr.pdf. Accessed 19 Jan 2015

12. Congressional Budget Office (2014) The Renewable Fuel Standard: issues for 2014 and beyond. Congress of the United States. https://www.cbo.gov/publication/45477. Accessed 19 Jan 2015

13. U.S. Environmental Protection Agency (2010) Regulation of fuels and fuel additives: changes to the renewable fuels standard program. Fed. Regist. 75. http://www.gpo.gov/fdsys/pkg/FR-201012-21/pdf/2010-31910.pdf. Accessed 19 Jan 2015

14. U.S. Environmental Protection Agency (2010) Renewable Fuel Standard Program (RFS2) regulatory impact analysis. Report No. EPA-420-R-10-006

15. Governor of California (2007) Executive Order S-01-07. http:// www.arb.ca.gov/fuels/lcfs/eos0107.pdf. Accessed 19 Jan 2015

16. California E.P.A. Air Resources Board (2011) Low Carbon Fuel Standard: Question and Answer Guidance Document (Version 1.0). http://www.arb.ca.gov/fuels/lcfs/LCFS_Guidance_\% 28Final_v.1.0\%29.pdf. Accessed 10 Feb 2015

17. Oregon Department of Environmental Quality (2015) Clean Fuels Program Regulations. http://www.deq.state.or.us/aq/cleanFuel/ regulations.htm. Accessed 19 Jan 2015

18. Center for Climate and Energy Solutions (2015) Low Carbon Fuel Standard. http://www.c2es.org/us-states-regions/policy-maps/lowcarbon-fuel-standard. Accessed 9 Jan 2015

19. Murphy CW, Kendall A (2013) Life cycle inventory development for corn and stover production systems under different allocation methods. Biomass Bioenergy 58:67-75. doi:10.1016/j.biombioe. 2013.08.008
20. Kaliyan N, Morey RV, Tiffany DG (2011) Reducing life cycle greenhouse gas emissions of corn ethanol by integrating biomass to produce heat and power at ethanol plants. Biomass Bioenergy 35:1103-1113. doi:10.1016/j.biombioe.2010.11.035

21. Sokhansanj S, Mani S, Tagore S, Turhollow AF (2010) Technoeconomic analysis of using corn stover to supply heat and power to a corn ethanol plant - part 1: cost of feedstock supply logistics. Biomass Bioenergy 34:75-81. doi:10.1016/j.biombioe.2009.10. 001

22. Mani S, Sokhansanj S, Tagore S, Turhollow AF (2010) Technoeconomic analysis of using corn stover to supply heat and power to a corn ethanol plant - part 2: cost of heat and power generation systems. Biomass Bioenergy 34:356-364. doi:10.1016/j. biombioe.2009.11.007

23. Ou L, Brown TR, Thilakaratne R, Hu G, Brown RC (2014) Technoeconomic analysis of co-located corn grain and corn stover ethanol plants. Biofuels Bioprod Biorefining 8:412-422. doi:10.1002/bbb. 1475

24. Kauffman N, Hayes D, Brown R (2011) A life cycle assessment of advanced biofuel production from a hectare of corn. Fuel 90:33063314. doi:10.1016/j.fuel.2011.06.031

25. California E.P.A. Air Resources Board (2014) CA-GREET 2.0 model and documentation. http://www.arb.ca.gov/fuels/lcfs/cagreet/ca-greet.htm. Accessed 19 Jan 2015

26. Wang M, Han J, Dunn JB, Cai H, Elgowainy, A (2012) Well-towheels energy use and greenhouse gas emissions of ethanol from corn, sugarcane and cellulosic biomass for US use. Environ Res Lett 7:045905. doi:10.1088/1748-9326/7/4/045905

27. Dunn JB, Mueller S, Kwon H, Wang MQ (2013) Land-use change and greenhouse gas emissions from corn and cellulosic ethanol. Biotechnol Biofuels 6:51. doi:10.1186/1754-6834-6-51

28. National Agricultural Statistics Service (2013) Quickstat Database. http://quickstats.nass.usda.gov/. Accessed 21 Aug 2014

29. Shapouri H, Gallagher PW, Nefstead W, Schwartz R, Noe S, Conway R (2010) 2008 Energy balance for the corn-ethanol industry. U.S. Department of Agriculture. Agricultural Economic Report Number 846. http://www.usda.gov/oce/reports/energy/ 2008Ethanol June final.pdf. Accessed 19 Jan 2015

30. Mueller S, Kwik J (2013) 2012 Corn ethanol: emerging plant energy and environmental technologies. http://ethanolrfa.3cdn.net/ fe5f4b7a4bdbc12101_2gm6bejk4.pdf. Accessed 19 Jan 2015

31. Humbird D, Davis R, Tao L, Kinchin C, Hsu D, Aden A (2011) Process design and economics for biochemical conversion of lignocellulosic biomass to ethanol: dilute-acid pretreatment and enzymatic hydrolysis of corn stover. Report No. NREL/TP-5100-47764

32. Wang M, Huo H, Arora S (2011) Methods of dealing with coproducts of biofuels in life-cycle analysis and consequent results within the U.S. context. Energy Policy 39:5726-5736. doi:10.1016/ j.enpol.2010.03.052

33. Argonne National Laboratory (2014) GREET 1 model. https:// greet.es.anl.gov/. Accessed 19 Jan 2015.

34. Spatari S, MacLean HL (2010) Characterizing model uncertainties in the life cycle of lignocellulose-based ethanol fuels. Environ Sci Technol 44:8773-8780. doi:10.1021/es102091a 